\title{
Evaluation of Pasture Allowance of Manganese for Ruminants
}

\section{Xiaoping GE}

Hohai University

\section{Fu Chen}

China University Mining and Technology

\section{Laraib Saqlain}

University of Sargodha

Jing Ma

China University Mining and Technology

Zafar Iqbal Khan ( $\nabla$ zikhan11@gmail.com )

University of Sargodha

Kafeel Ahmad

University of Sargodha

Ifra Saleem Malik

University of Sargodha

Asma Ashfaq

University of Sargodha

Razia Sultana

University of Sargodha

Mudasra Munir

University of Sargodha

Muhammad Nadeem

University of Sargodha Pakistan

Muhammad Umer Farooq Awan

Government College University Lahore

Muhammad Sohail

Hohai University

\section{Research Article}

Keywords: Seasonal variation, Health risk index, Bio concentration, Pollution Load Index, Pakistan

Posted Date: May 13th, 2021 
DOI: https://doi.org/10.21203/rs.3.rs-431969/v1

License: (c) (1) This work is licensed under a Creative Commons Attribution 4.0 International License. Read Full License 


\section{Abstract}

The aim of study was to access the Mn contamination in soil, forages and animals. Heavy metal pollution is a matter of prime significance in natural environment. Through food chain toxicity of heavy metals and their bioaccumulation potential are transferred into humans. Higher concentrations of metallic compounds are toxic to living organisms but these are essential to maintain body metabolism. Intake of food crops polluted with heavy metals is chief food chain channel for human exposure. Animals are exposed to heavy metal stress by the intake of richly contaminated food crops those are chief part of food chain. We collected samples of soil, plant, animal blood, hair and faeces to find contamination through wet digestion process in lab and metal analysis. Different forages were collected to study $\mathrm{Mn}$ calculation was our major concern in this study. Our present findings also emphasized on the assessment of bio-concentration factor (BCF). We also calculated other significant indices i.e. Pollution load index (PLI), daily intake of metal (DIM), Health Risk Index (HRI) and Enrichment factor (EF). While the experimentation result showed different concentrations of metal in different seasons. When the Mn concentration in forages was $(20.01-28.29 \mathrm{mg} / \mathrm{kg})$ and in soil $(5.27-8.90 \mathrm{mg} / \mathrm{kg})$. Soil samples showed higher level of (PLI) Pollution load index. Bio-concentration of iron was $(2.59-4.21 \mathrm{mg} / \mathrm{kg})$. It can be concluded as regular monitoring of the level metal is essential evaluate the contamination status.

\section{Introduction}

Manipulation and the accessibility of some crucial metals in the body of living being is produced by level of Bio-concentrations of some heavy metals. In food chain heavy metal load is measured by degree of contamination at specific area. Toxicity of heavy metals is measured by assessment of biomagnifications in trophic levels from soil-forages-animal continuum and its bioaccumulation beside this by evaluation of contamination in fodder crops and water (Has-Schon et al., 2006; Saleemi et al., 2019). Water life is also good bio-indicator of heavy metal level in water ecosystem, chemical analysis of heavy metal contents in water bodies is useful method for their bio-monitoring (Liu et al., 2007).

Group of elements that possess density greater than $5 \mathrm{~g} / \mathrm{cm} 3$ are categorized as heavy metals (Stobrawa and Lorenc-Plucinska, 2008). Heavy metal pollution is dangerous and risky for environment of biosphere; it includes contamination of soil, air and water. When heavy metals interact with each other they show different toxic effects than individual contaminant (MacFarlan and Burchett, 2002). Plant anatomy and metabolic compounds are affected by heavy metals and extinctions of species can occur in this world. Various elements that are absorbed by plants are termed as toxic elements even at low concentration. Heavy metal toxicity cause cellular death due to oxidative stress. With the passage of time plants have evolved the detoxification mechanism to reduce the harmful effects of heavy metal accumulation and exposure (Yadev, 2010). Worldwide industrial revolution has polluted the water and soil with many detrimental chemical compounds including trace metals. When these metals leach into trophic chain are harmful to plants and also cause severe damages to human health (Kumar et al., 2013). Heavy metals are persistant and non-degradable by chemical degradation or microbial degradation unlike other metalloids and organic compounds (Bolan et al., 2014). In addition to this antagonistic, synergistic and 
additive effects on plant growth are produced by heavy metals when they collectively show their effects to plants.

In the upper layer of earth crust there are some non-degradable, non-damageable and natural metals are found trace metals (Ugulu, 2015a). These metals are potentially toxic having long term effects on food chain and they should be remediate actively (Khan et al., 2019a). For synthesize of hormone, regulation of metabolism and to controlling enzyme mode of action; minerals are perform a vital role. Mineral deficiencies and toxicosis are related with the metabolical functioning, effects of nutrients and treatment of mineral related disorders.

Livestock is major and principal part of Pakistani agricultural practices. Its contribution to net domesticated production of country is $12 \%$; it makes possible the availability of daily used dairy products. Communities living in countryside are seriously trusting on this sector for earnings (Chandio et al., 2016). Food based requirements of grazing ruminants are accomplished by forage and mineral nutrients present in pasture land. On the other hand, tissue of animals, for example kidney and liver, and animal blood samples are significant indicators of potential toxicity than forage because of grazing ruminants select different nutritional and diet forages (Khan et al., 2009).

Microelements are elements that required in lesser amount for animals and plants these are present in environment are essential for organisms for sustainability of life i.e. minerals and vitamins. Macronutrients and micronutrients of all types fulfill the particular nutritious needs of animals and forages (Pais and Jones, 1997).In soil-forage-animal continuum heavy metals and other mineral nutrients perform a significant role in metabolic, catabolic, biochemical, biological, chemical and enzymatic activities of living cell in organisms. In soil-forage-animal continuum heavy metals and other mineral nutrients perform a significant role in metabolic, catabolic, biochemical, biological, chemical and enzymatic activities of living cell in organisms.

\section{Materials And Methods}

\section{Study Area:}

District Mianwali is located in south-western region of province Punjab. This district is consists of the plains of western area of salt range. It is situated near the Sakesar hill. Mianwali district has boundaries with Khushab, D.I Khan, Bhakkar and Bannu districts. This district is part of Sargodha Division. Temperature of this area ranges from $47^{\circ} \mathrm{C}$ maximum and $19^{\circ} \mathrm{C}$ minimum per annum. In Mianwali the maximum rain fall occur in July about $6.6 \mathrm{~mm}$ annual mean rain fall is about $3.3 \mathrm{~mm}$. Soil condition of this area characterize as loamy, sandy and clay soil. Pea nut, mung, mash, mustard, Eruca, fennel, wheat, barley and oat are important crops. Forest cover area is very low because trees are used as fuel and timber. Canal irrigation system is very less developed, only a little area is irrigated with Indus river irrigation system (Ghani et al., 2016; Qureshi et al., 2007).

\section{Sample collection from sites}


In district Mianwali four sites were selected for sampling. The 3 samples of agricultural soil, forages and animal blood, hair and faeces were taken to examine the metal profile of soil-forage-animal continuum. The samples were taken from Wan bhachran site, Mianwali, Esakhel and Piplan. S1 (Summer), S2 (Autumn) and S3 (Winter) was selected for sampling. The samples were taken randomly from sites.

\section{Soil sample collection}

In the district Mianwali four sites were selected to collect the samples. 3 samples of soil were collected with equal distances in the field. Stainless steel auger was used to dig up the upper layer of soil about 12$15 \mathrm{~cm}$ (Siddique et al., 2019). These samples were packed into plastic bags to avoid the mixing of other chemical compounds into it. Samples were stored in laboratory and labeled then metal analysis was performed. For each sample three composite samples were made. The collected samples were firstly air then oven drying at $72^{\circ} \mathrm{C}$ for 2 days. The samples were placed in incubators at $70{ }^{0} \mathrm{C}$ temperature for 5 days.

\section{Forage sample collection}

Sterilized apparatus were used to collect the forage samples. Forage and soil were collected from same field and place. Only those forages were selected for taking samples that are used as common feed of livestock. 3 samples of each forage plant were taken from the sampling area. The samples were washed with distilled water to clear impurities and dirt. These samples were dried to eliminate moisture in the freshly collected samples. The collected samples were dried for further process. These are following species that were selected for sampling.

\begin{tabular}{|lll|}
\hline Calotropis procera & Apocynaceae & Apple of Sodom \\
\hline Dactyloctenium aegyptium & Poaceae & Egyptian crowfoot grass \\
\hline Parthenium hysterophorus & Asteraceae & carrot grass \\
\hline Rumex dentatus & Polygonaceae & Jangali palak \\
\hline Ziziphus jujube & Rhamnaceae & red date, Chinese date \\
\hline
\end{tabular}

\section{Animal blood plasma, hair and faeces sample collection}

Blood samples of cow, buffalo and sheep of Mianwali was taken in 2020. Young animals within age of two years were selected for sampling. Blood was collected from four sites of district Mianwali. Animal blood was calculated from 10 animals (Cow, buffalo and sheep) each from each sampling site and heavy metal evaluation was done. Sterilized syringe was used to obtain the blood samples. The grazing ruminant's blood was taken from the vein. The vacuum was created in evacuated tubes while collecting blood to minimize the extent of clotting. The blood was collected in heparinized Na-citrate voiles quickly. For 15 minutes blood was centrifuged at $3000 \mathrm{rpm}$ and blood plasma was separated. Polyethylene tubes 
were used to store the blood plasma and frozen at $-20{ }^{\circ} \mathrm{C}$. Hair and faeces samples were also collected and stored for the further digestion process.

\section{Sample measurement and preparation}

Arrangement and preparation of samples involves the digestion process. This method of digestion is called wet digestion. It has following steps.

\section{Digestion 2.Dilution 3. Filtration 4. Analysis of samples}

Acid and hydrogen per oxide is used for complete digestion process. Distilled water is added after digestion into prepared samples for dilution purpose. After that filtration of samples occur. In next step Atomic Absorption Spectrophotometer (AAS) is an apparatus through which metal analysis is done.

\section{Apparatus and chemicals for digestion}

Chemicals that are used for digestion process includes the $10 \mathrm{~mL}$ nitric acid ,70\% Sulphuric acid $\left(\mathrm{H}_{2} \mathrm{SO}_{4}\right)$, $50 \%$ Hydrogen peroxide $\left(\mathrm{H}_{2} \mathrm{O}_{2}\right)$ and newly synthesized condensed water or distilled $\left(\mathrm{H}_{2} \mathrm{O}\right)$. The apparatus

for digestion includes digestion flasks of $100 \mathrm{ml}$, measuring cylinder $(50 \mathrm{ml})$, beakers $(50 \mathrm{ml})$ and $(100 \mathrm{ml})$, pipette $(10 \mathrm{ml})$, filter paper, stirrer, hotplate and gloves.

\section{Digestion of soil, forages and Animal samples}

Digestion of soil and forages and animal samples (blood, hair and faeces) include various steps. First of all the samples are air dried and followed by oven dried process at $72^{\circ} \mathrm{C}$ for 5 days until the moisture content is removed. When plants are completely dried they weighed with electrical balance. Standard procedure of digestion was applied to digest the samples (Siddique et al., 2019). 1gm sample was weighed by electrical balance and placed in a beaker of $50 \mathrm{ml} .10 \mathrm{ml}$ nitric acid was added to beaker and was kept overnight. Hot plate was used for digestion of particular sample by pouring $\mathrm{H} 2 \mathrm{O} 2$ drop wise until solution becomes transparent. Cooling at room temperature was done. For dilution purpose $50 \mathrm{ml}$ distilled water was added to solution. To filter the solution Whatman filter paper of $42 \mu \mathrm{m}$ was used. Then this prepared solution was kept in plastic bottles for metal profile evaluation.

Blood samples collected from the Mianwali district were stored and freezed at $-20{ }^{0} \mathrm{C}$. For digestion process the samples were from freezer and digested with same standard procedure as applied to soil and forages (Siddique et al., 2019). Hair sample was sun dried and was cut into pieces of 1.0-2.9 cm. Deionized water was used to wash the samples and ethanol was also applied to wash. Oven drying process was carried out and for 4 hours and then desiccator cooling was performed (Hashem et al., 2017). Faeces samples were collected from cow, buffalo and sheep after air drying and oven dry the samples were submitted for digestion (Nicholson et al., 1999).

\section{Metal profile evaluation analysis}


The prepared samples were then analyzed for metal contents by Atomic Absorption Spectrophotometer (Perkin-Elmer Corp., 1980). Nutritional minerals that was evaluated in the sample was Mn. Standard solution was prepared to get the standardized curve. The metal analysis was done by running the samples through Atomic Absorption Spectrophotometer. This apparatus is equipped with a graphite furnace. The each metal is measured according to value of standard solution. The amount of each metal occurring in the sample is obtained in absolute farm. While sample is run through the Atomic Absorption Spectrophotometer the little quantity of sample is sprayed at the flame. Atomic resonance absorption line by element is calculated and measured. The apparatus is convenient for analysis. Any radiation that is emitted by flame had no effect on the working of apparatus. The absorption method is independent of the excitation potential of the spectral line used.

\section{Evaluation Indices:}

\section{Bio concentration Factor (BCF):}

For assessment of metal $(\mathrm{mg} / \mathrm{kg})$ transport from agricultural soil and forages that are growing on this soil, a BCF is applied (Cui et al., 2004).

BCF for soil to forage

$(B C F)=$ Level of metal in forage /Level of metal in soil

\section{Pollution load index (PLI)}

Liu et al. (2005) described a formula which was used to find this indices.

Pollution Load Index $=(\underline{\mathbf{M}}) \underline{\mathbf{S}}$

(M)RS

Where,

$(M) I S=(\mathrm{mg} / \mathrm{kg})$ Concentration of metal that occurs in soil to investigate

(M)RS= Soil reference value of metal

Referene values for soil in Mn was taken as 25.5 suggested by Hassan et al. (2013).

\section{Enrichment factor (EF)}

Formula for Enrichment factor is described by Buat-Menard and Chesselet (1979).

Enrichment factor $(E F)=($ Conc. of metal in plant/Conc. of metal in soil) sample

(Conc. of metal in plant/Conc. of metal in soil) standard 
According to Hassan et al. (2013) standard reference value for Zn was used $25.5 \mathrm{mg} / \mathrm{kg}$.

\section{Daily intake of metals (DIM)}

Daily intake of metal (DIM) can be calculated by following equation

DIM $=$ Cfactor $\times C_{\text {metal }} \times D_{\text {food intake }} / B_{\text {average weight }}$ Sajjad et al. (2009).

where,

$C_{\text {metal }}$ is the concentration of metals in forages,

$D_{\text {food intake }}$ is the daily intake of forages,

$B_{\text {average weight }}$ is the average body weight.

For calculating this daily intake of metal the conversion factor was taken 0.085 (Jan et al., 2010). Daily intake metal for cow was calculated by using animal body weight $600 \mathrm{~kg}$ and daily forage intake $12 \mathrm{~kg}$ while for sheep body weight was taken $75 \mathrm{~kg}$ and daily forage intake $1.3 \mathrm{~kg}$ (Johnsen and Aaneby, 2019). To calculate the DIM for buffalo body weight was taken $550 \mathrm{~kg}$ and daily forage intake (TDI) was taken $12.5 \mathrm{~kg}$ (Yang et al., 2020).

\section{Health Risk Index (HRI)}

Health risk index is the ratio of daily intake of metals in the forages to oral reference dose (RfD) and was calculated by the help formula (USEPA, 2002).

Health risk index $(H R I)=D I M / R_{f} D$

DIM = Daily intake of heavy metal

$\mathrm{R}_{\mathrm{f}} \mathrm{D}=$ Oral reference dose

An $\mathrm{HRI}>1.0$ for any single metal indicates that the health of consumer population is at risk or it is carcinogenic (USEPA, 2013). According to USEPA (2010) oral reference dose for Mn was taken as 0.041 $(\mathrm{mg} / \mathrm{kg} / \mathrm{day})$.

\section{Results}

\section{Soil, Forages and animals ANOVA}

In the results of analysis of variance for $\mathrm{Mn}$ showed the non-significant effect in season, soil and soil $\mathrm{x}$ season. The analysis of variance showed the significant effect of $\mathrm{Mn}$ in season. Non-significant effect of Mn was shown in soil and Season $x$ soil. The analysis of variance for Mn showed the significant effect in 
season but non-significant effect was observed by Animal, Source, Season x Animal, Season x Source, Animal x Source and Season x Animal x Source (Table 1).

\section{Table 1}

Analysis of variance table for Mn concentration in soil, forages and animals

\begin{tabular}{|c|c|c|}
\hline Source & Degree of freedom & Mean Square \\
\hline Soil (Mn) & 2 & $4.192^{n s}$ \\
\hline \multicolumn{3}{|l|}{ Season } \\
\hline Soil & 4 & $0.897^{\mathrm{ns}}$ \\
\hline Season $x$ soil & 8 & $2.556^{\mathrm{ns}}$ \\
\hline Forage (Mn) & 2 & $93.279 * \star \star$ \\
\hline \multicolumn{3}{|l|}{ Season } \\
\hline Soil & 4 & $5.311^{\mathrm{ns}}$ \\
\hline Season $x$ soil & 8 & $11.509^{\mathrm{ns}}$ \\
\hline Animal (Mn) & 2 & $23.747^{\star \star \star}$ \\
\hline \multicolumn{3}{|l|}{ Season } \\
\hline Animal & 2 & $1.057^{\mathrm{ns}}$ \\
\hline Source & 2 & $0.629^{n s}$ \\
\hline Season x Animal & 4 & $0.822^{n s}$ \\
\hline Season $x$ Source & 4 & $1.576^{\mathrm{ns}}$ \\
\hline Animal x Source & 4 & $0.709^{n s}$ \\
\hline Season x Animal x Source & 8 & $0.602^{n s}$ \\
\hline
\end{tabular}

The level of $\mathrm{Mn}$ in soil samples had variation in amounts. The Mn level varied in the range of $5.27 \mathrm{mg} / \mathrm{kg}$ to $8.90 \mathrm{mg} / \mathrm{kg}$ minimum and maximum respectively (Table 2). The minimum concentration of $\mathrm{Mn}$ was evaluated in the Soil samples of $R$. dentatus forage. The minimum Mn concentration was calculated during time period of $\mathrm{S} 1$ sampling (Fig. 1). The maximum values were observed by Soil of forage $D$. aegyptium during S2. Our finding for Mn concentration in soil was lower than permissible value of 437 $\mathrm{mg} / \mathrm{kg}$ described by NRC (2001).

The $\mathrm{Mn}$ concentration in forages was different in each sample. The minimum amount of Mn was present in $20.1 \mathrm{mg} / \mathrm{kg}$ in C. procera forage during S1 (Table 2). The maximum concentration of $\mathrm{Mn}$ was found in 
$28.29 \mathrm{mg} / \mathrm{kg}$ during the months of S3 (Fig. 2).. Higher concentration of Mn was present in Z. jujube. The Mn amount in forages was below than critical limits of $200 \mathrm{mg} / \mathrm{kg}$ recommended by FAO/WHO (2001).

The $\mathrm{Mn}$ concentration in blood was noticed varied from (1.00-2.16 mg/l) the minimum amount was observed in sheep of S1and maximum concentration was observed in cow of S3 (Table 3). The Mn level in blood of current study was higher than $0.51 \mathrm{mg} / \mathrm{l}$ (Kalita et al., 2006). The hair had Mn values ranged from minimum to maximum $(1.04-2.66 \mathrm{mg} / \mathrm{kg})$ in buffalo during $\mathrm{S} 1$ and cow during $\mathrm{S} 3$ respectively (Fig. 3). The Mn showed different concentration in feaces samples varied from lower to higher (0.55$2.35 \mathrm{mg} / \mathrm{kg}$ ). The minimum value was found in cow during S1. The maximum value was found in sheep during $\mathrm{S} 2$.

Figure 3: The Mn concentration in Animals blood, hair and faeces in different seasons ( $\mathrm{mg} / \mathrm{kg})$

Table 2

The mean concentration of $\mathrm{Mn}(\mathrm{mg} / \mathrm{kg})$ in soil and forages

\begin{tabular}{|llll|}
\hline Samples & \multicolumn{3}{l|}{ Seasons } \\
\cline { 2 - 4 } & S 1 & S 2 & S 3 \\
\hline Mn in Soil of forages & & & \\
\hline Soil of forage C. procera & $7.76 \pm 0.320$ & $7.29 \pm 0.612$ & $7.45 \pm 0.359$ \\
\hline Soil of forage D. aegyptium & $6.76 \pm 0.649$ & $8.90 \pm 0.289$ & $7.89 \pm 0.857$ \\
\hline Soil of forage P. hysterophorus & $7.52 \pm 0.608$ & $6.43 \pm 0.614$ & $7.54 \pm 1.187$ \\
\hline Soil of forage R. dentatus & $5.27 \pm 0.442$ & $8.04 \pm 0.781$ & $7.92 \pm 0.834$ \\
\hline Soil of forage Z. jujube & $6.92 \pm 0.312$ & $7.27 \pm 0.603$ & $8.55 \pm 1.188$ \\
\hline
\end{tabular}

Table 3: The Mean concentration of $\mathrm{Mn}$ in animals blood, hair and faeces $(\mathrm{mg} / \mathrm{kg})$. 


\begin{tabular}{|lllll|}
\hline Source & Animal & S1 & S2 & S3 \\
\hline Blood & & $1.27 \pm 0.243$ & $1.45 \pm 0.201$ & $2.16 \pm 0.386$ \\
& Cow & & & \\
& & $1.21 \pm 0.247$ & $1.53 \pm 0.311$ & $2.02 \pm 0.302$ \\
& Buffalo & & & \\
\hline & & $1.00 \pm 0.179$ & $1.93 \pm 0.374$ & $1.83 \pm 0.362$ \\
& Sheep & & & \\
\hline & & $1.13 \pm 0.168$ & $1.85 \pm 0.379$ & $2.66 \pm 0.424$ \\
& Cow & & & \\
& & $1.04 \pm 0.148$ & $2.06 \pm 0.397$ & $2.06 \pm 0.382$ \\
& Buffalo & & & \\
\hline & & $1.08 \pm 0.239$ & $2.55 \pm 0.463$ & $1.91 \pm 0.351$ \\
& Sheep & & & \\
\hline Faeces & & $0.55 \pm 0.039$ & $2.01 \pm 0.342$ & $1.88 \pm 0.268$ \\
& Cow & & & \\
\hline & & $1.27 \pm 0.276$ & $1.67 \pm 0.269$ & $1.97 \pm 0.378$ \\
& Buffalo & & & \\
\hline & & & & \\
\hline & & & & \\
\hline & & & & \\
\hline
\end{tabular}

\section{Bio-concentration Factor (BCF) of Mn}

Mn bio-concentration was in the range from $2.59-4.21 \mathrm{mg} / \mathrm{kg}$. The minimum amount of bioconcentration was observed in $C$. procera during $\mathrm{S} 1$ while the maximum concentration was found in $P$. hysterophorus during time intervals of S2 (Table 4).

\section{Pollution Load Index (PLI) of Mn}

The level of PLI for Mn ranged from the $0.207-0.349 \mathrm{mg} / \mathrm{kg}$. The maximum range was observed in $D$. aegyptium during S2 while the minimum level was noticed in $R$. dentatus during S1 (Table 4).

\section{Enrichment Factor (EF) of Mn}

The enrichment factor was ranged from the $0.242-0.393 \mathrm{mg} / \mathrm{kg}$. The maximum concentration was depicted by $C$. procera during intervals of $\mathrm{S} 1$ while the minimum amount was found by the $P$. 
hysterophorus in S2 (Table 4).

\section{Daily Intake Metal (DIM) of Mn}

The DIM (daily intake metal) trend for Mn was found between $0.029-0.055 \mathrm{mg} / \mathrm{kg}$. The lowest amount of was depicted by sheep of S1 while the highest amount was noticed in buffalo during S3 (Table 5).

\section{Health Risk Index (HRI) of Mn}

The health risk index (HRI) of Mn varied within a range from $0.722-1.33 \mathrm{mg} / \mathrm{kg}$. The smallest values were found sheep in S1 while the greatest value was noticed in buffalo of S3 (Table 5).

Table 4: Pollution indexes for $\mathrm{Mn}$ in soil and forages.

\begin{tabular}{|c|c|c|c|}
\hline \multirow[t]{2}{*}{ Forages } & \multicolumn{3}{|c|}{ Seasons } \\
\hline & S 1 & S 2 & S 3 \\
\hline
\end{tabular}

\begin{tabular}{|llll|}
\hline BCF (Mn) & & & \\
\hline C. procera & 2.59 & 3.69 & 3.77 \\
\hline D. aegyptium & 3.61 & 3.09 & 3.36 \\
\hline P. hysterophorus & 2.93 & 4.21 & 3.54 \\
\hline R. dentatus & 3.87 & 3.22 & 3.46 \\
\hline Z. jujube & 3.81 & 3.36 & 3.31 \\
\hline PLI (Mn) & 0.304 & 0.286 & 0.292 \\
\hline C. procera & & & \\
\hline D. aegyptium & 0.265 & 0.349 & 0.309 \\
\hline P. hysterophorus & 0.295 & 0.252 & 0.296 \\
\hline R. dentatus & 0.207 & 0.315 & 0.310 \\
\hline Z. jujube & 0.271 & 0.285 & 0.335 \\
\hline
\end{tabular}




\begin{tabular}{|llll|}
\hline EF $(\mathbf{M n})$ & & & \\
\hline C. procera & 0.242 & 0.346 & 0.353 \\
\hline D. aegyptium & 0.337 & 0.289 & 0.314 \\
\hline P. hysterophorus & 0.274 & 0.393 & 0.331 \\
\hline R. dentatus & 0.361 & 0.301 & 0.323 \\
\hline Z. jujube & 0.357 & 0.314 & 0.309 \\
\hline
\end{tabular}

Table 5: Daily intake metal and Health risk index for Mn.

\begin{tabular}{|llllllllll|}
\hline Forages & \multicolumn{1}{l}{ Cow } & \multicolumn{4}{c}{ Buffalo } & \multicolumn{4}{c|}{ Sheep } \\
\cline { 2 - 8 } & S1 & S2 & S3 & S1 & S2 & s3 & s1 & S2 & S3 \\
DIM (Mn) & & & & & & & & & \\
\hline
\end{tabular}

\begin{tabular}{|llllllllll|}
\hline C. procera & 0.034 & 0.046 & 0.048 & 0.039 & 0.052 & 0.054 & 0.029 & 0.039 & 0.041 \\
\hline D. aegyptium & 0.041 & 0.047 & 0.045 & 0.047 & 0.053 & 0.051 & 0.036 & 0.041 & 0.039 \\
\hline P.hysterophorus & 0.037 & 0.046 & 0.045 & 0.043 & 0.052 & 0.052 & 0.032 & 0.039 & 0.039 \\
\hline R. dentatus & 0.035 & 0.044 & 0.047 & 0.039 & 0.049 & 0.053 & 0.030 & 0.038 & 0.040 \\
\hline Z. jujube & 0.045 & 0.042 & 0.048 & 0.051 & 0.047 & 0.055 & 0.039 & 0.036 & 0.042 \\
\hline
\end{tabular}

\begin{tabular}{|llllllllll|}
\hline HRI $(\mathbf{M n})$ & & & & & & & & & \\
\hline C. procera & 0.834 & 1.12 & 1.17 & 0.947 & 1.27 & 1.32 & 0.722 & 0.968 & 1.01 \\
\hline D. aegyptium & 1.01 & 1.14 & 1.10 & 1.15 & 1.29 & 1.25 & 0.876 & 0.990 & 0.953 \\
\hline P.hysterophorus & 0.914 & 1.12 & 1.11 & 1.04 & 1.27 & 1.26 & 0.792 & 0.972 & 0.959 \\
\hline R. dentatus & 0.845 & 1.07 & 1.14 & 0.960 & 1.22 & 1.29 & 0.732 & 0.929 & 0.983 \\
\hline Z. jujube & 1.09 & 1.01 & 1.17 & 1.24 & 1.15 & 1.33 & 0.948 & 0.878 & 1.02 \\
\hline
\end{tabular}

\section{Discussion}

Soil contained Mn concentration in safe limits as compare to the suggested value of $2000 \mathrm{mg} / \mathrm{kg}$ recommended by USEPA (1997). The current investigation for Mn soil concentration was found below the results by Xu et al. (2017). Our present $\mathrm{Mn}$ level in soil samples was greater as compare to the recorded amounts by Yaylalı-Abanuz (2011). The Mn concentration in found similar with the evaluations given by Uren (2013). The Mn usually occurred in the form of oxides with other metals, its most abundant oxide 
form was observed with iron metal in soil fraction. These two metals have high affinity with each other so their mobility from soil is reduced even negligible Yaylalı-Abanuz (2011).

The Mn amounts in forage were observed similar with the investigations given by Underwood and Suttle (2010). In this study the investigation for Mn was greater as compare to recorded values by Lindström et al. (2013). This study of $\mathrm{Mn}$ found lower the concentration of $\mathrm{Mn}$ in forage as compare to the observation by Udiba et al. (2014). The current findings were found higher than those given by Spann et al. (2010). Manganese is essential for the forage growth and it is component of chlorophyll and enzyme oxidases. Mn amount in soil varies from specie to specie and individual to individual it is also affected by soil properties and drainage system (Udiba et al., 2014).

Cow blood Mn concentration in this study was found lower than the suggested values of Luna et al. (2019). These findings were greater for Mn cow blood than reported values of Popovic et al. (2010). Sheep blood Mn level was found similar with those values given by Popovic et al. (2010). In this work the $\mathrm{Mn}$ level in buffalo blood was found lower as compare with Abd El-Hady et al. (2006). This work for Mn in buffalo hair was lower as compare to recorded values by Huo and Shen (2020). Mn concentration in buffalo hair in this present study was lower as compare to the values given by Abd El-Hady et al. (2006). El- Ashry et al. (2012) reported the similar Mn concentration of cow manure as compare to this work. Our work for cow faeces Mn concentration was found in accordance with the reported work by Raghu (2013). Numerous clinical effects of supplement diet enriched with Mn cause increase in bulk and reduction in growth, nervous alterations, anemia, intestinal lesions, of triglyceride cholesterol and increase plasma $\mathrm{Mn}$ concentration (McDowell, 1992).

Our present investigation for Mn bio-concentration was found greater as compare to the Sakizadeh et al. (2016). Yang et al. (2014) gave the lower values for the Mn bio-concentration than present work. This current study was found in accordance with the recorded values of Yang et al. (2013).

The amount of Mn pollution load index was observed below as compare to the Harikumar and Jisha. (2010). The PLI was found similar lower than in this present work for Mn as compare to investigations of Sukri et al. (2018). This value was lower in PLI Mn was lower than those values given by Izah et al. (2017).

The enrichment factor of $\mathrm{Mn}$ was below than the narrated values given by the Ghazzal et al. (2020). The Mn enrichment factor was observed in accordance with values Mn (PLI) with Sukri et al. (2018). In present findings the Mn pollution load index was found lower than the values given by Enuneku et al. (2017).

The present concentration of daily intake of metal was in accordance with narrated values by Ghazzal et al. (2020). The present findings for DIM for Mn were observed greater as compare to the El-Ashry et al. (2012). Our results for HRI manganese was lower as compare to the Ghazzal et al. (2020). These present findings for $\mathrm{Mn}$ health risk index were greater than those given by Khan et al. (2018). 


\section{Conclusion}

It was concluded that seasonal changes gave different fluctuating concentrations of metals and sites also gave fluctuating metal readings in soil-forage-animal continuum. In soil and forage samples collected from semi-arid environment was found safe according to FAO/WHO. In animal samples Mn was found toxic according to NRC standards. Bio-concentration factor was noticed greater than 2 while pollution load index, enrichment factor, daily intake metal and health risk index for Mn was less than 1.

\section{Declarations}

\section{Ethics Declarations}

Conflict of interest: The authors declare that they have no conflict of interest.

Ethical approval: The authors declare that the manuscript has not been published previously.

Ethical statement: All the study protocols were approved by the institutional animal ethics committee, University of Sargodha (Approval No. 25-A18 IEC UOS). All the experiments performed complied with the rules of the National Research Council and all methods were performed keeping in view the ethical principles regarding animals accordance with relevant guidelines and regulations.

Consent to participate: All authors voluntarily to participate in this research study.

Consent to publish: All authors consent to the publication of the manuscript.

Availability of data and materials: All data generated or analyzed during this study are included in this published article.

\section{Funding:}

This work was supported by the National Natural Science Foundation of China (Nos. 51974313 and 41907405) and the Natural Science Foundation of Jiangsu Province (BK20180641).

Contributions: XGE, FC, JM LS and MHS were responsible for writing the manuscript. ZIK and KA MS supervised the study. AA, ISM, RS, MM, MHS was responsible for conducting the experiments and the data analysis. MN and MUFA, XGE, FC, JM were responsible for analyzing and interpreting the data. All authors read and approved the final manuscript.

\section{References}

1. Abd El-Hady MAA, El-Ayouty SA, Khinizy AE (2006) Effect of trace element supplementation to suckling buffalo calves. Egyptian J Anim Prod 43:169-184

2. Bolan N, Kunhikrishnan A, Thangarajan R, Kumpiene J, Park J, Makino T, Krikham MB, Scheckel K (2014) Remediation of heavy metal (loid) s contaminated soils-to mobilize or to immobilize? 
Journal of hazardous materials 266:141-166

3. Buat-Menard P, Chesselet R (1979) Variable influence of atmospheric flux on the trace metal chemistry of oceanic suspended matter. Earth Plan Sci Lett 42:398-411

4. Chandio AA, Yuansheng J, Magsi H (2016) Agricultural sub-sectors performance: an analysis of sector-wise share in agriculture GDP of Pakistan. International Journal of Economics Finance 8:156162

5. Cui YJ, Zhu YG, Zhai RH, Chen DY, Huang YZ, Qui Y, Liang JZ (2004) Transfer of metals from near a smelter in Nanjing, China. Environ Int 30:785-791

6. El Ashry GM, Hassan AAM, Soliman SM (2012) Effect of Feeding a Combination of Zinc, Manganese and Copper Methionine Chelates of Early Lactation High Producing Dairy Cow. Food \& Nutrition Sciences. 3

7. Enuneku A, Biose E, Ezemonye L (2017) Levels, distribution, characterization and ecological risk assessment of heavy metals in road side soils and earthworms from urban high traffic areas in Benin metropolis, Southern Nigeria. Journal of environmental chemical engineering 5:2773-2781

8. FAO/WHO (2001) Codex Alimentarius Commission. Food additive and contaminants. Joint FAO/WHO Food Standards Programme, ALINORM 01/12A. 1-289

9. FAO/WHO.2001. Codex Alimentarius Commission. Food additive and contaminants. Joint FAO/WHO Food Standards Programme ALINORM 01/12A. 1-289

10. FAOSTAT.2013. FAO Statistics Division 2013.www.faostat.fao.org

11. Ghazzal M, Khan ZI, Ahmad K, Mehmood N, Mahpara S, Nadeem M, Munir M, Wajid K, Sohail M, Malik IS, Ashfaq A, Bashir H, Akhtar M, Akhter P (2020) Incidence and health risk assessment of grazing animals due to toxic metal residues ( $\mathrm{Cd}$ and $\mathrm{Mn}$ ) in Sahiwal, Sargodha. Pure Applied Biology (PAB) 9:872-883

12. Harikumar PS, Jisha TS (2010) Distribution pattern of trace metal pollutants in the sediments of an urban wetland in the southwest coast of India

13. Has-Schön E, Bogut I, Strelec I (2006) Heavy metal profile in five fish species included in human diet, domiciled in the end flow of River Neretva (Croatia). Archives of environmental contamination toxicology 50:545-551

14. Huo B, Shen X (2020) Study of rickets and osteomalacia in Tibetan gazelle. Pakistan Journal of Zoology 52:1751-1759

15. Izah SC, Bassey SE, Ohimain El (2017) Assessment of pollution load indices of heavy metals in cassava mill effluents contaminated soil: a case study of small-scale processors in a rural community in the Niger Delta, Nigeria. Bioscience Methods. 8

16. Jan FA, Ishaq M, Khan S, Ihsanullah I, Ahmad I, Shakirullah M (2010) A comparative study of human health risks via consumption of food crops grown on wastewater irrigated soil (Peshawar) and relatively clean water irrigated soil (lower Dir). J Hazard Mater 179:612-621 
17. Johnsen IV, Aaneby J (2019) Soil intake in ruminants grazing on heavy-metal contaminated shooting ranges. Science of the total environment 687:41-49

18. Kalita DJ, Sarmah BC, Bhattacharyya BN, Milli DC (2006) Serum mineral profile of assam local goat of hills zone during different physiological stages. Indian J Anim Res 40:93-94

19. Khan ZI, Ashraf M, Ahmad K, Valeem EE, McDowell LR (2009) Mineral status of forage and its relationship with that of plasma of farm animals in Southern Punjab. Pakistan Pak J Bot 41:67-72

20. Khan Zl, Safdar H, Ahmad K, Wajid K, Bashir H, Ugulu I, Dogan Y (2019a) Health risk assessment through determining bioaccumulation of iron in forages grown in soil irrigated with city effluent. Environ Sci Pollut Res 26:14277-14286

21. Khan ZI, Ugulu I, Umar S, Ahmad K, Mehmood N, Ashfaq A, Bashir H, Sohail M (2018) Potential toxic metal accumulation in soil, forage and blood plasma of buffaloes sampled from Jhang. Pakistan Bulletin of environmental contamination toxicology 101:235-242

22. Kumar S, Asif MH, Chakrabarty D, Tripathi RD, Dubey RS, Trivedi PK (2013) Expression of a rice Lambda class of glutathione S-transferase, OsGSTL2, in Arabidopsis provides tolerance to heavy metal and other abiotic stresses. Journal of hazardous materials 248:228-237

23. Lindström BEM, Frankow-Lindberg BE, Dahlin AS, Wivstad M, Watson CA (2013) Micronutrient concentrations in common and novel forage species and varieties grown on two contrasting soils. Grass Forage Sci 68:427-436

24. Liu WH, Zhao JZ, Ouyang ZY, Söderlund L, Liu GH (2005) Impacts of sewage irrigation on heavy metal distribution and contamination in Beijing, China. Environment international 31:805-812

25. Liu W, Chen J, Lin X, Fan Y, Tao S (2007) Residual concentrations of micropollutants in benthic mussels in the coastal areas of Bohai Sea, North China. Environmental Pollution 146:470-477

26. Liu WH, Zhao JZ, Ouyang ZY, Soderlund L, Liu GH (2005) Impacts of sewage irrigation on heavy metals distribution and contamination in Beijing, China. Environ Int 31:805-812

27. Luna D, López-Alonso M, Cedeño Y, Rigueira L, Pereira V, Miranda M (2019) Determination of Essential and Toxic Elements in Cattle Blood: Serum vs Plasma. Animals 9:465

28. MacFarlane GR, Burchett MD (2002) Toxicity, growth and accumulation relationships of copper, lead and zinc in the grey mangrove Avicennia marina (Forsk.) Vierh. Marine Environmental Research 54:65-84

29. McDowell L (1992) Doing gender: feminism, feminists and research methods in human geography. Transactions of the institute of British Geographers. 399-416

30. National Research Council (NRC) (2001) Nutrient requirements of domestic animals. National Academy of Science Press, Washington, DC.1

31. National Research Council, Board on Agriculture, Committee on the Nutrient Requirements of Small Ruminants, Division on Earth, \& Life Studies. 2007. Nutrient requirements of small ruminants: sheep,

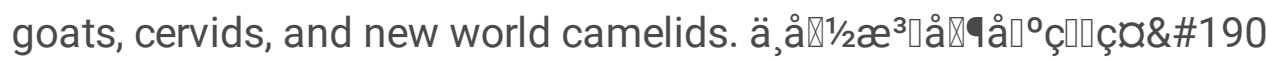

32. Pais I, Jones Jr JB (1997) The handbook of trace elements. CRC Press 
33. Popovic D, Bozic T, Stevanovic J, Frontasyeva M, Todorovic D, Ajtic J, Jokic VS (2010) Concentration of trace elements in blood and feed of homebred animals in Southern Serbia. Environmental Science Pollution Research 17:1119-1128

34. Raghu V (2013) Distribution of trace elements in certain ecological components and animal products in a dairy farm at Tirupati, Chittoor District, Andhra Pradesh, India. Environmental monitoring assessment 185:10431-10440

35. Sajjad K, Farooq R, Shahbaz S, Khan MA, Sadique M (2009) Health risk assessment of heavy metals for population via consumption of vegetables. World Applied Science Journal 6:1602-1606

36. Sakizadeh M, Mirzaei R, Ghorbani H (2016) Accumulation and soil-to-plant transfer factor of lead and manganese in some plant species in Semnan province, central Iran. Iranian Journal of Toxicology 10:29-33

37. Saleemi MK, Tahir MW, Abbas RZ, Akhtar M, Ali A, Javed MT, Hassan ZU (2019) Amelioration of toxicopathological effects of cadmium with silymarin and milk thistle in male Japanese quail (Coturnix japonica). Environ Sci Pollut Res 26:21371-21380

38. Spann AJ, Carter JN, McDowell LR, Wilkinson NS, Myer RO, Maddox MK, Brennan M (2010) Forage mineral concentrations and mineral status of beef cattle grazing cool season pastures in Northwestern Florida, emphasizing magnesium. Communications in soil science and plant analysis. $41,472-481$

39. Stobrawa K, Lorenc-Plucińska G (2008) Thresholds of heavy-metal toxicity in cuttings of European black poplar (Populus nigra L.) determined according to antioxidant status of fine roots and morphometrical disorders. Science of the total environment 390:86-96

40. Sukri NS, Aspin SA, Kamarulzaman NL, Jaafar NF, Ghazi RM, Shafiee NS, Yaacob SH, Kedria FK, Zakaria MP (2018) Assessment of metal pollution using enrichment factor (EF) and pollution load index (PLI) in sediments of selected terengganu rivers, Malaysia. Malaysian Journal of Fundamental Applied Sciences 14:235-240

41. Udiba UU, Odey MO, Jibril AH, Gauje B, Sikemi O, Sule AM, Mohammed HA, Abdullahi M (2014) Manganese and Magnesium Status of Forage Grasses, and It's Implications for Grazing Animals, Dareta Village, Zamfara, Nigeria. International Research Journal of Pure and Applied Chemistry. 203-212

42. Ugulu I (2015 a) Determination of heavy metal accumulation in plant samples by spectrometric techniques in Turkey. Applied Spectroscopy Reviews. 50, 113-151

43. Underwood EJ, Suttle NF (2010) The mineral nutrition of livestock (4th edition). CABI Publishing, Wallingford, UK.1

44. Uren NC (2013) Cobalt and manganese. In Heavy Metals in Soils.Springer, Dordrecht. 335-366

45. USEPA (Environmental Protection Agency) (2010) Integrated Risk Information System

46. USEPA (US Environmental Protection Agency). 2002.Region 9, Preliminary Remediation Goals. Office of Research and Development, Washington, DC, USA 
47. USEPA.2010. Integrated Risk Information System (IRIS). Arsenic, inorganic (CASRN 7440-38-2), Cadmium (CASRN 7440-43-9). http://cfpub.epa.gov/ncea/iris/index.cfm?

fuseaction=iris.showSubstanceList

48. USEPA., 1997. Exposure factors handbook. Office of research and development, Washington

49. USEPA.2013. Integrated Risk Information System (IRIS). United States Environment Protection Agency

50. World Health Organization (WHO).1998. Quality Control Methods for Medicinal Plant Materials, Geneva, Switzerland.1

51. Xu X, Chen C, Wang P, Kretzschmar R, Zhao FJ (2017) Control of arsenic mobilization in paddy soils by manganese and iron oxides. Environmental Pollution 231:37-47

52. Yadav SK (2010) Heavy metals toxicity in plants: an overview on the role of glutathione and phytochelatins in heavy metal stress tolerance of plants. South African Journal of Botany 76:167179

53. Yang QW, Zeng Q, Xiao F, Liu XL, Pan J, He JF, Li ZY (2013) Investigation of manganese tolerance and accumulation of two Mn hyperaccumulators Phytolacca americana L. and Polygonum hydropiper L. in the real Mn-contaminated soils near a manganese mine. Environmental earth sciences 68:1127-1134

54. Yang S, Liang S, Yi L, Xu B, Cao J, Guo Y, Zhou Y (2014) Heavy metal accumulation and phytostabilization potential of dominant plant species growing on manganese mine tailings. Frontiers of Environmental Science Engineering 8:394-404

55. Yang Y, Khan Zl, Ahmad K, Arshad N, Rehman SU, Ullah MF, Wajid K, Mahpara S, Bashir H, Nadeem N, Ahmad T, Munir M, Malik IS, Ashfaq A, Ugulu I, Ma J, Chen F, Ahmad T (2020) Does the chromium element in forages and fodders grown in contaminated pasture lands cause toxicity in livestock: assessing the potential risk. Rev Chim 71:397-405

56. Yaylalı-Abanuz G (2011) Heavy metal contamination of surface soil around Gebze industrial area, Turkey. Microchemical Journal 99:82-92

\section{Figures}




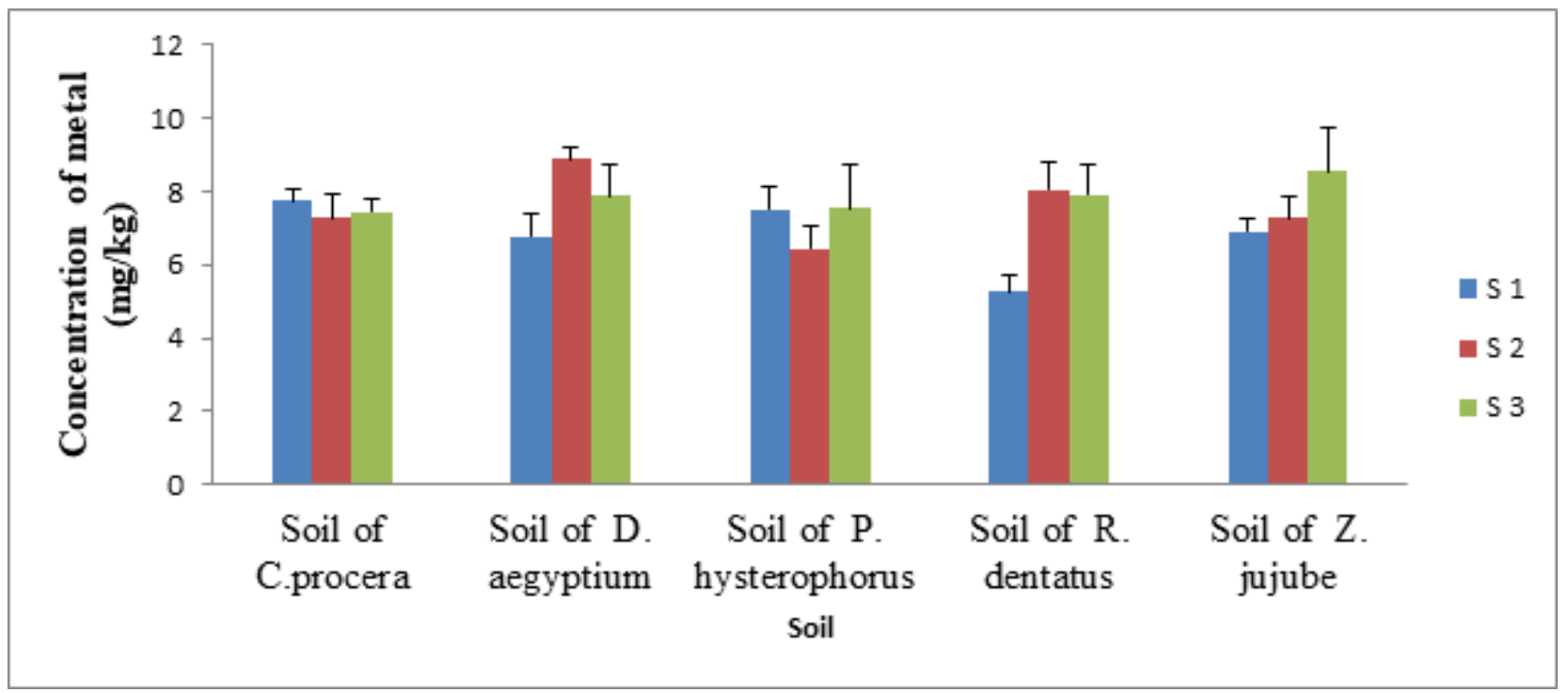

\section{Figure 1}

Mean Concentration of $\mathrm{Mn}$ in soil of during different season $(\mathrm{mg} / \mathrm{kg}$ )

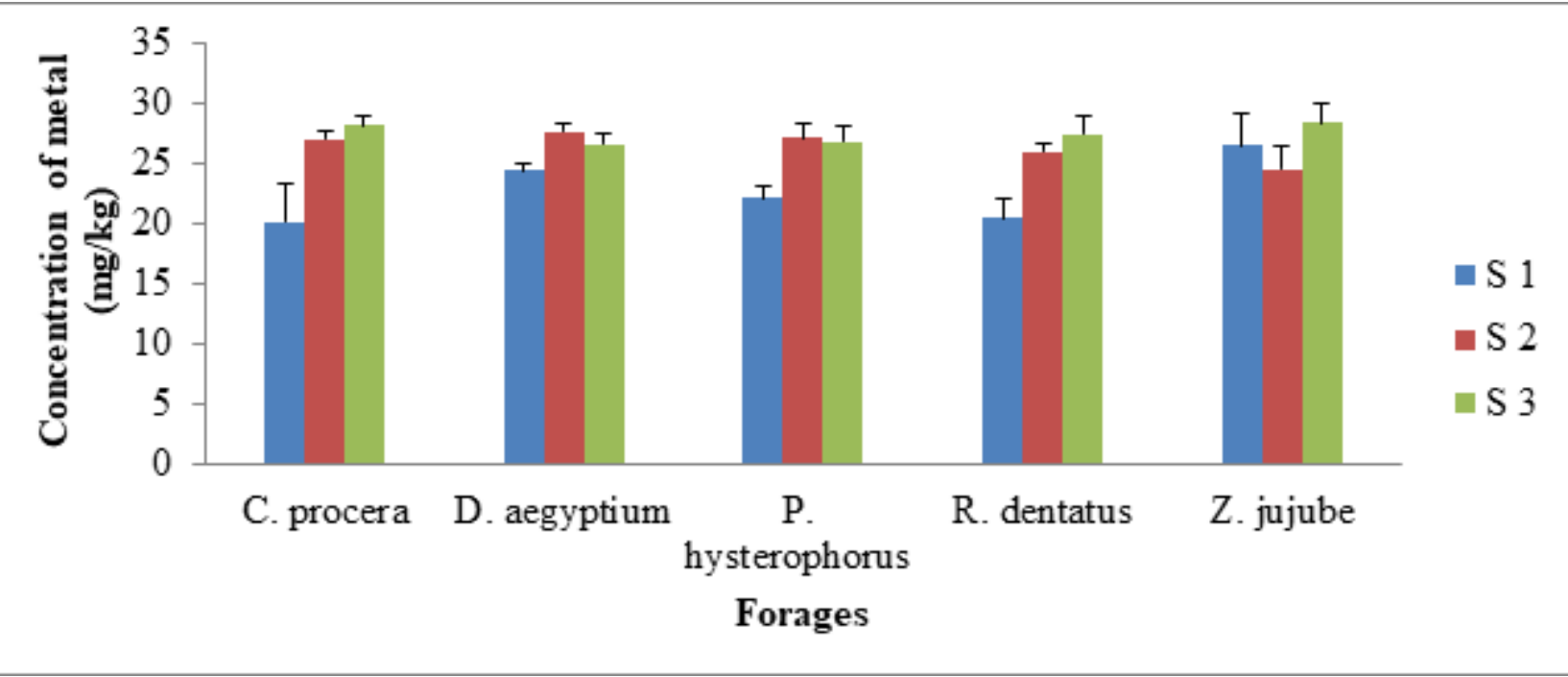

Figure 2

The $\mathrm{Mn}$ concentration in forages $(\mathrm{mg} / \mathrm{kg})$ in different seasons 


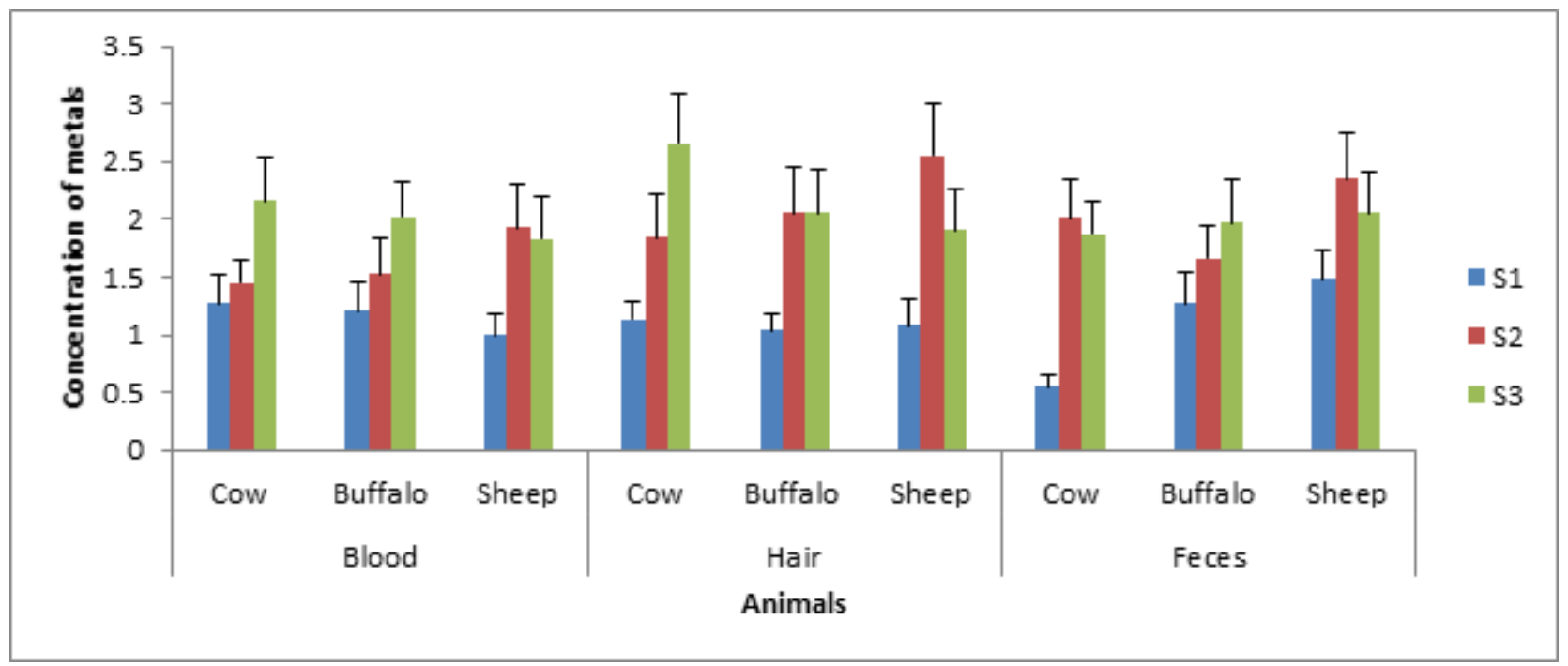

Figure 3

The Mn concentration in Animals blood, hair and faeces in different seasons ( $\mathrm{mg} / \mathrm{kg}$ ) 